العـــــــد السابع وإلثلاثون

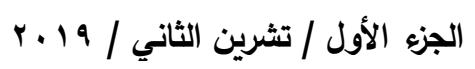

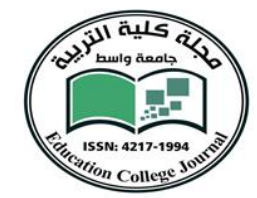

جامعة واسط

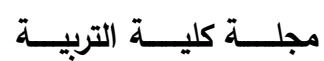

\title{
صور الألم في الآخرة
}

الباحث: منصور نعيم علي أ.م.د. علاء حسين خلف

\section{جامعة واسط / كلية التربية للعلوم الانسانية}

ال.لملخص عددت طرق الدنيا وكلٌ منها يقود إلى هدف معين، بينما اختصت الآخرة بطريقين فقط: طريقُ مؤنس، وآخر موحش، ينتهي الأول إلى نعيم لا يفنى، وينتهي الآخر إلى ألٍٍ لا يُطاق، ويمكن للإنسان أن يختار أحد هذين الطريقين من خلال أعماله في الحياة الدنيا، فمن وقع اختياره على الطريق الموحش كان لابذّ له من المرور بمحطات الألم! ليرسم صوراً مرعبة! وأهوالاً مخيفة! تتوعت أشكالها، وأساليبها، وأختلف روادها، بحسب الجرم الذي اقترفه كلُ منهم، فإنّهم أُحرقوا حتى ذابت جلودهم وتجددت! وسُقوا من الحميم والقيح! وأُطعموا من الزقوم والضريع! وسُحبوا على وجوههم في جهنم! كل تلك الصور، وغيرها كشفت عنها الآيات القرآنية المباركات، وإنّ الحكمة من ذكر تلك الصور في القرآن الكريم كان لسَوق الموعظة لجميع الخلق، عسى وأن يصححوا مسارهم، ويُجوّدوا زادهم لتلك الرحلة التي لا عودة منها أبداً .

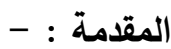

بسم الله الرحمن الرحيم والحمد لله رب العالمين، والصلاة والسلام على المبعوث رحمة للعالمين محمد المصطفى وآله الميامين، وأصحابه المنتبين، ومن سار على نهجه إلى قيام يوم الدين .

أمّا بعد: فقد أستعمل الله سبحانه وتعالى أسلوب الترغيب والترهيب في تقويم سلوك الخلق، وتهديد العاصين منهم بأليم العقاب، وسوء المآل، ومن جملة هذه الأساليب وصف النار وأهوالها! وحال العاصين فيها! وتصوير تلك المشاهد بأبشع الصور ! وأدق التفصيلات! كي ينظر القارئ لتلك الآيات

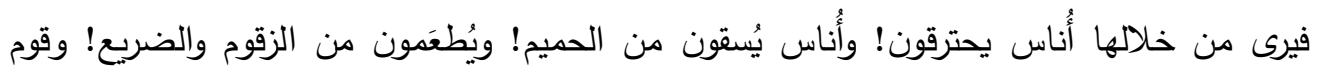
يُسحبون على وجوههم! وقوم يُكون على جباههم وجنوبهم! ومن حروف تلك الآيات يسمع عويل

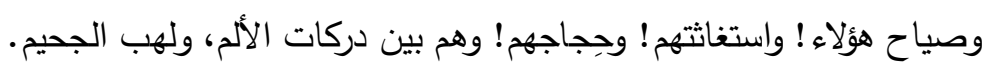
لقد كثفت في هذا البحث عن خمس صور لألم الآخرة ذُكرت في القرآن الكريم، وقد تألّف بحثي هذا

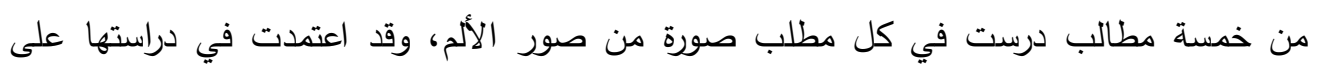


منهجين من مناهج البحث العلمي، وهما منهج التفسير الوصفي، والمنهج التحليلي، إذ لابد من تحليل

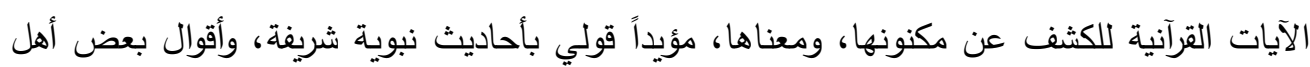
العلم . اليات

وقد توصلت بعد هذه الدراسة إلى مجموعة نتائج بينتها باختصار في نهاية البحث. لا أدّعي الكمال لهذا البحث؛ لأنّ الكمال لله وحده، ولكنّي أعترف بأنّي بذلتُ جهاً كبيراً في إنجازه

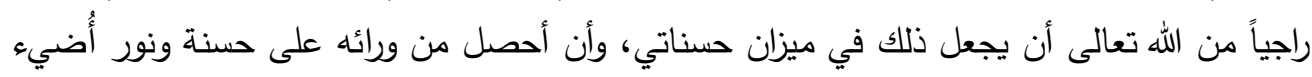

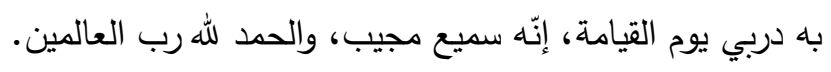

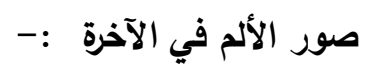

أكّد الله سبحانه في كتابه الكريم أنّ الألم الذي يمس العاصين في الآخرة أشد وأقسى من الألم الذي

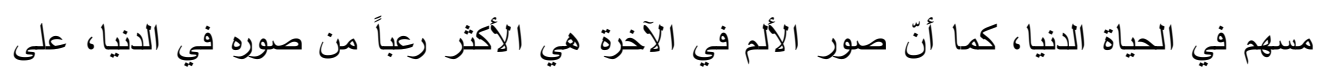

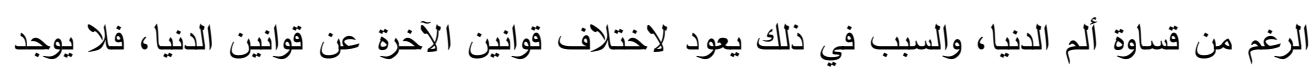
موت في الآخرة يخلّص المتألمين مما هم فيه! ولا تتلف أعضاءهم حتى تتنهي معاناتهم، بل تتجدد! كما أنّ حواسهم لا تفقد الإحساس! ولا تتعطل! بل تستمر في إحساسها بكل ما حولها رغم شدّة النار

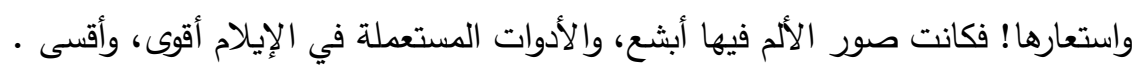

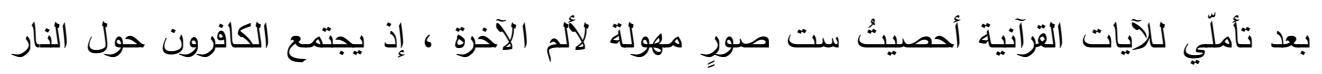

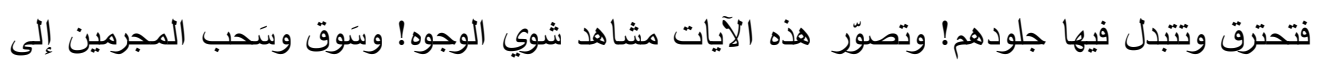

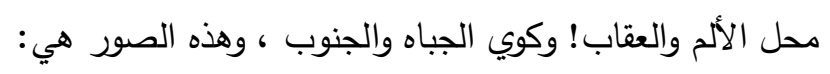

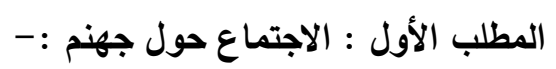

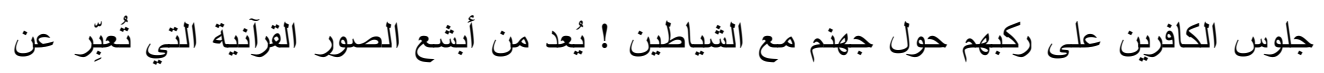

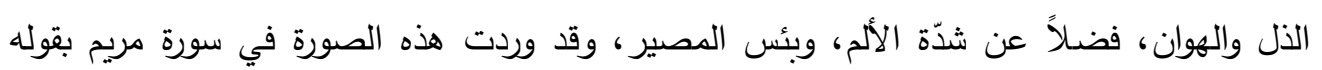

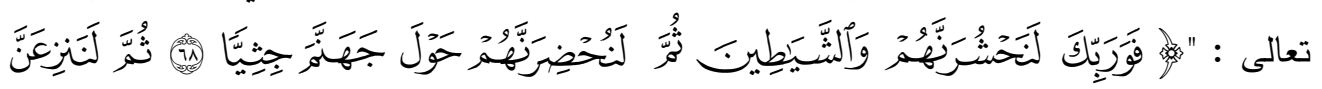

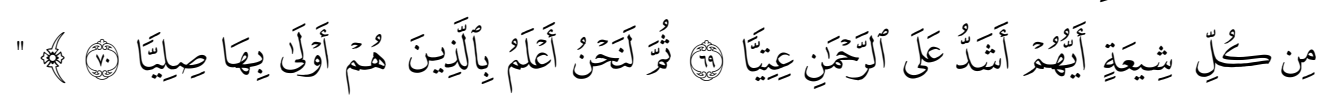


إنّ الخطاب في هذه الآية موجّه إلى النبي محمد (;) إذ أقسم سبحانه بنفسه بأنّه سيجمع الكافرين

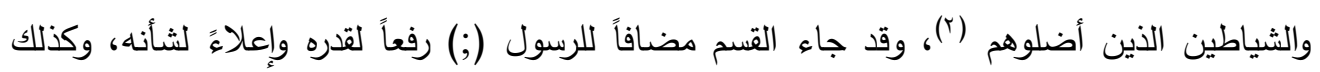

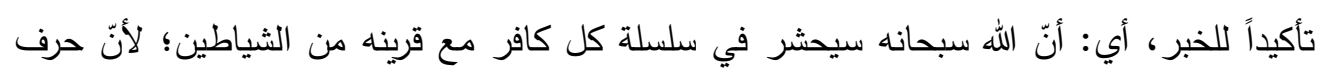

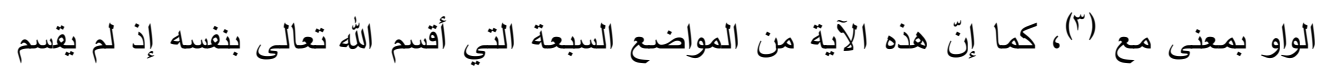

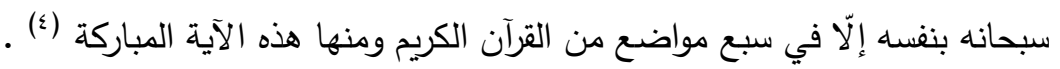

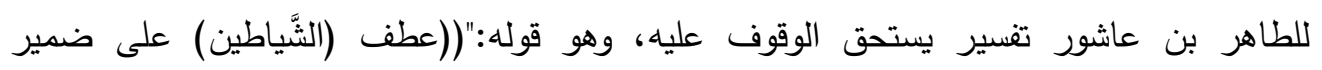

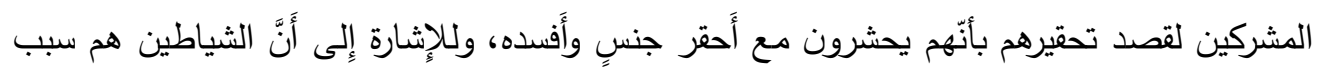

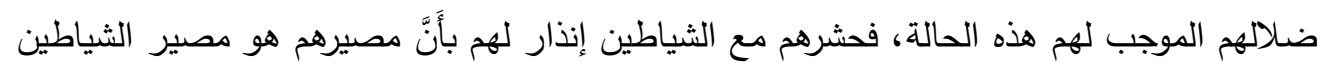
. ${ }^{(\circ)} " 1($

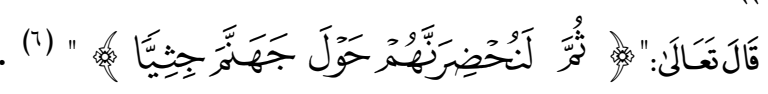

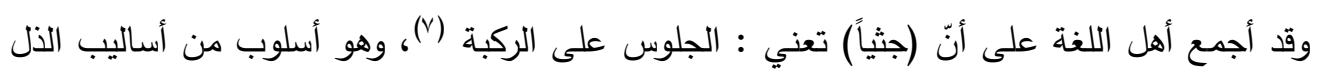

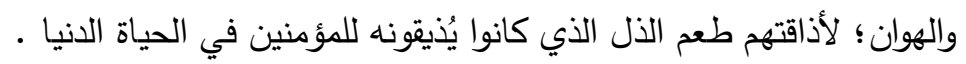

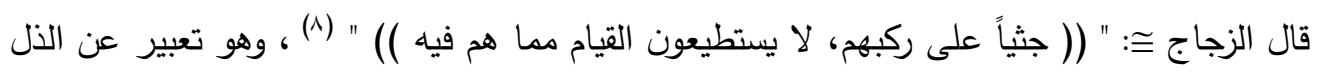

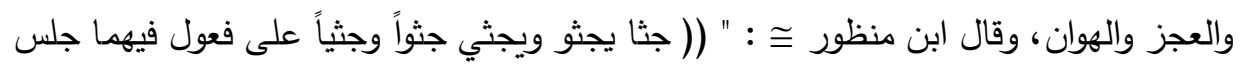

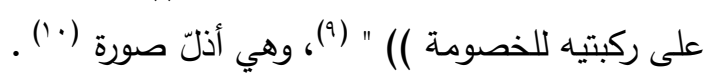

أتفق المفسرون على كيفية مثولهم وطريقة جلوسهم -جثيّاً على ركبهر- واختلفوا في تحديد الدكان

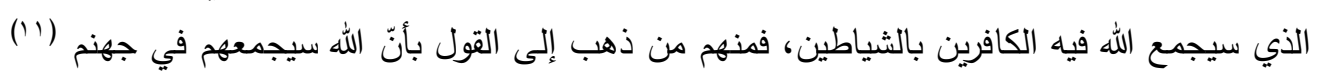

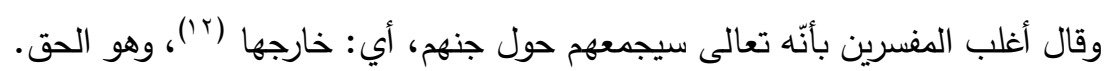

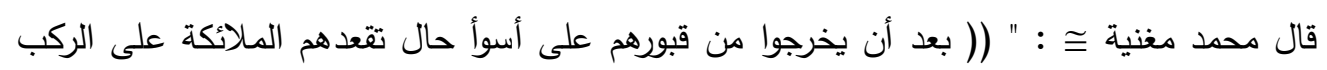

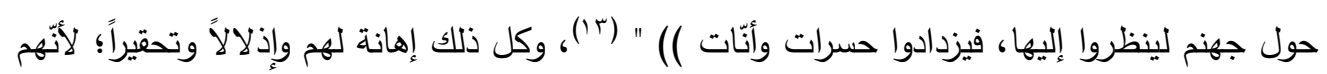

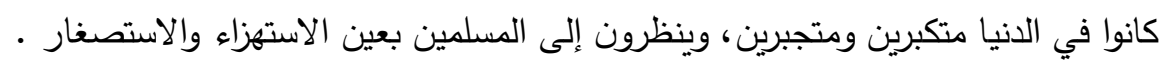

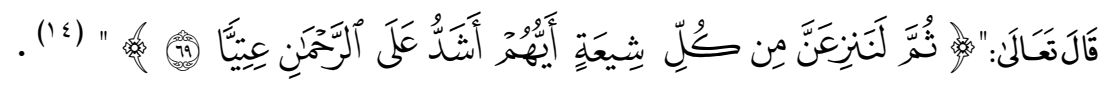

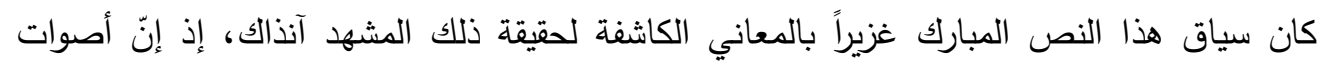

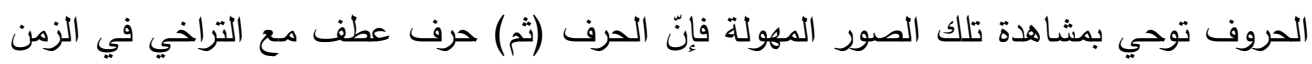
(01)، أي: يطول انتظارهم حولها، والنزع هو : " (( جذبه من مقرّه كنزع القوس عن كبده )) " (1'). 
العـــــــد السابع وإلثلاثون

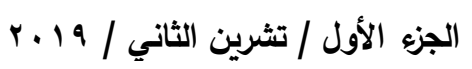

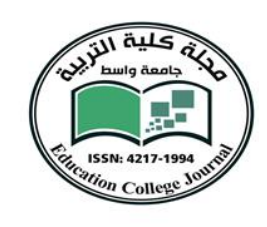

جامعة واسط مجلـــة كليـــة التربيــــة

وقيل : هو الجذب والاقتلاع بقوة وشدة (V)، كل هذه المعاني تقيد معنى القسوة والعنف في أخذ الأشد تمرداً وضلالاً، بعد إحضار أهل النار وجلوسهم حول جهنم، يبدأ سبحانه بألقاء أشدهم كفراً وضـالاًاً

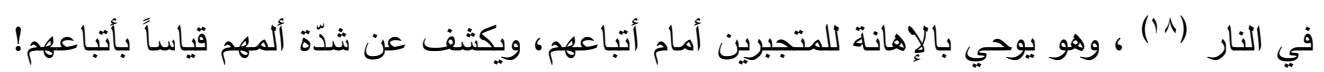

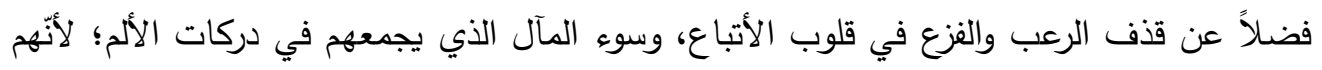

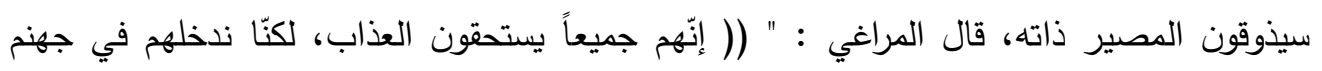
بحسب عتيّهم وتجبرهم في كفرهم () " (9 (') .

تصوّر الآيتان مشهاً من مشاهد القيامة، وما يحصل للضالين، والمضلين، من أهوال في ذلك اليوم

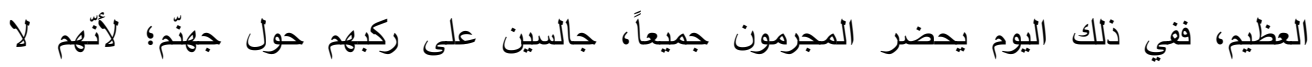

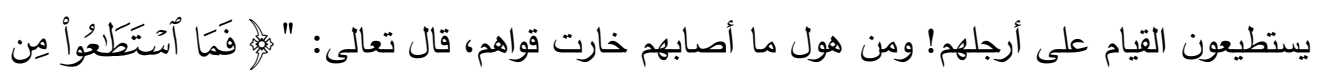

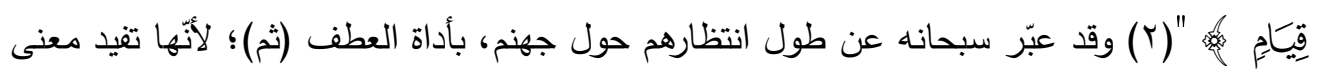

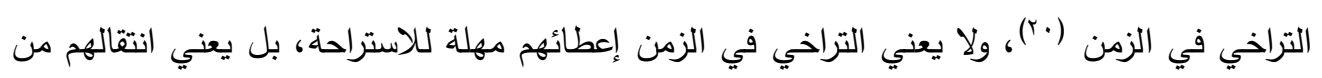

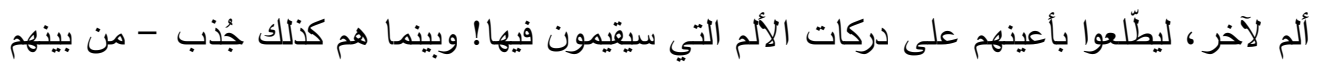

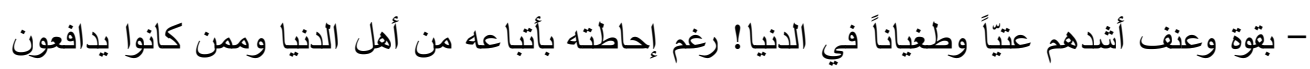

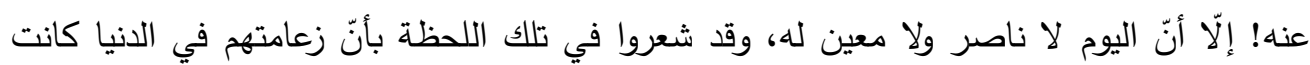

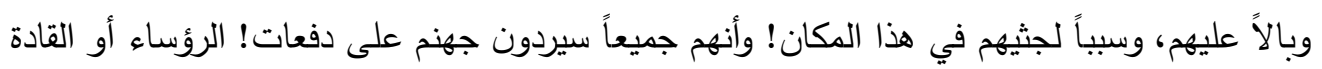

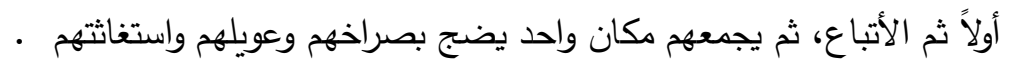

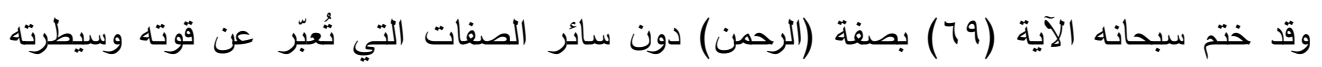

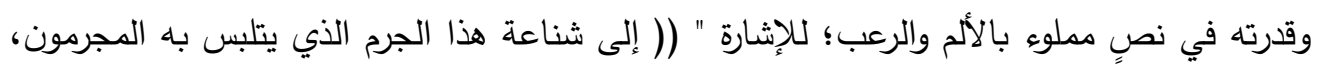

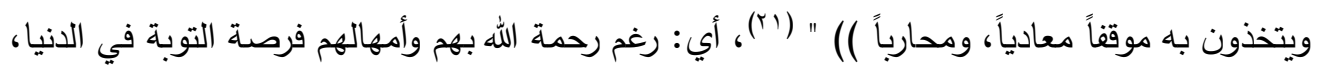

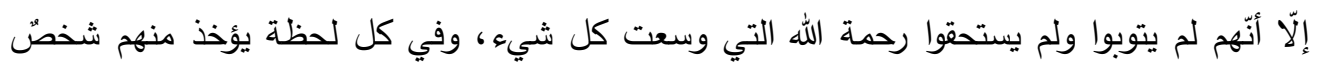

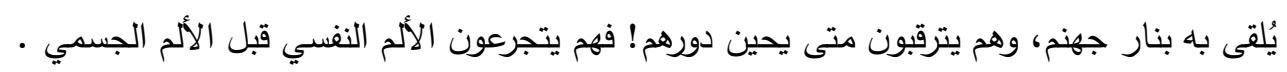


العـــــــد السابع وإلثلاثون

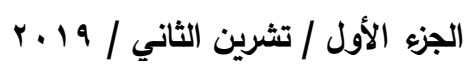

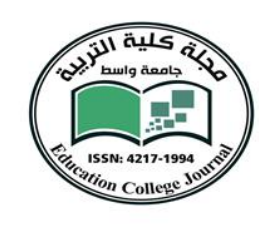

جامعة واسط مجلـــة كليـــة التربيــة

المطلب الثاني : تجدد الجلود :-

تنتشر على الجلد نهايات عصبية تقوم بنقل ما يشعر به الإنسان من بردٍ، وحرٍ ، وألمٍ، وضغطٍٍ،

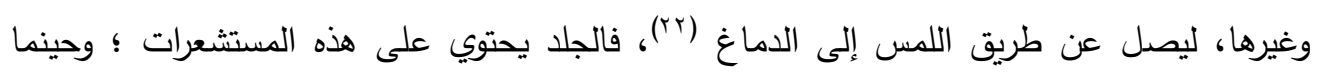
يتلف هذا الجلد؛ بسبب حرارة جهنم يتجدد مرّة أخرى! وتتجدد معه تلك الأجهزة؛ ليستمر الثعور

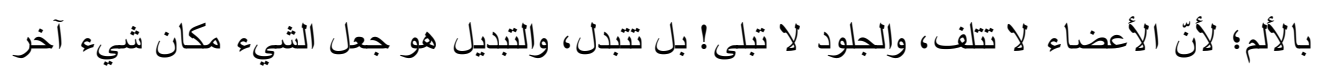

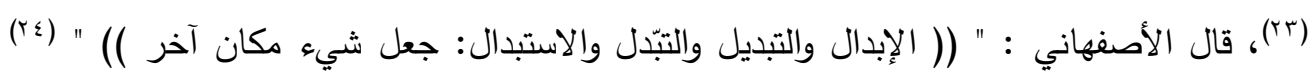

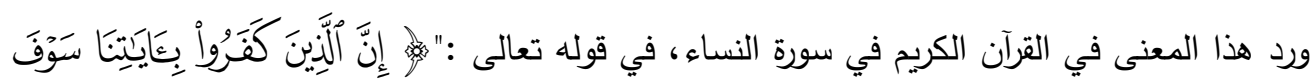

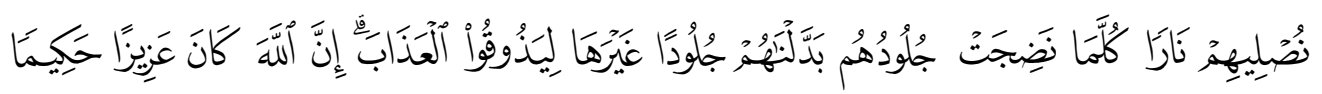
( $(10)$ " a يتوعد الله أهل النار بالألم المتجدد، إذ كلما بليت جلودهم وانصهرت جعل لهم جلوداً جديدة تشعر بالألم! ولكن ما ذنب هذه الجلود الجديدة التي لم ترتكب معصية بعد حتى تقاسي الألم بسبب معصية

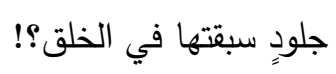
طرح أحد الملحدين هذا التساؤل في حضرة الإمام الصادق (الئلئك) بقوله: " هب هذه الجلود عصيت

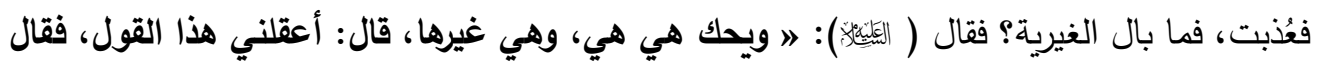

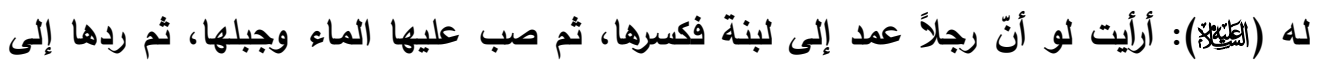
هيئتها الأولى، ألم تكن هي هي، وهي غيرها؟ فقال: بلى، أمتع الله بك " " (זب)، وهذا ما قال به

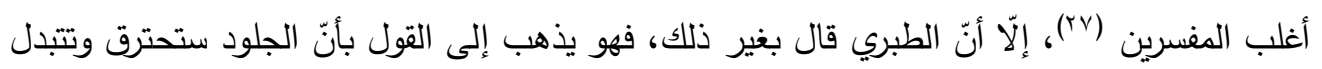

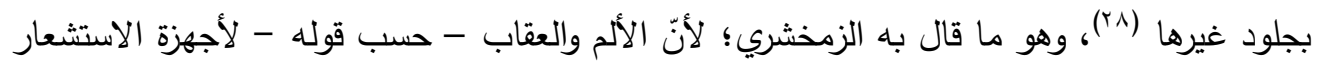

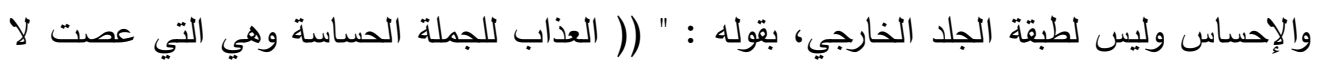

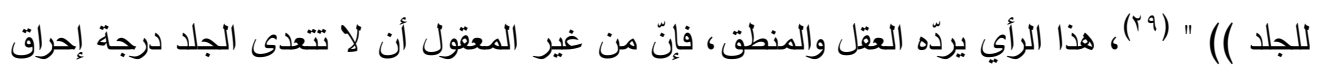

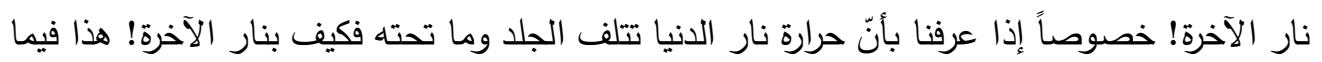
إذا كانت النهايات العصبية (المستشعرات) تحت الجلد، وليست فيه، وهو من المستحيل أيضاً؛ لأنّ 
العـــــــد السابع وإلثلاثون

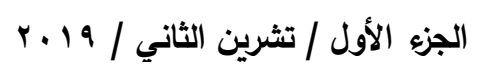

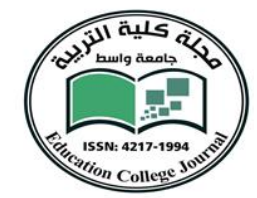

جامعة واسط

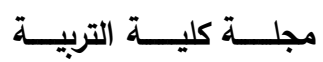

الجلد لو كان فاصلاً بينها وبين المحسوسات لما تمكنت هذه الأجهزة من العمل بصورة صحيحة، فإنّ هذه النهايات العصبية متغلغلة فيه ولا يمكن فصلها عن الجلد .

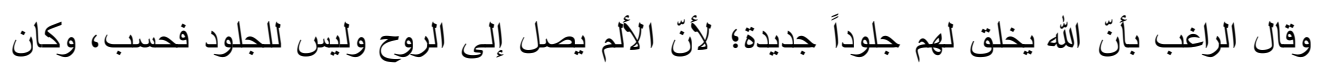

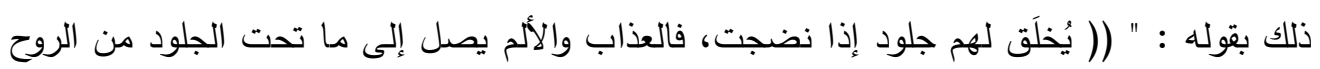

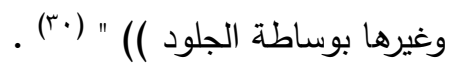

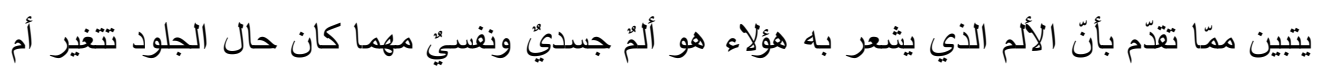

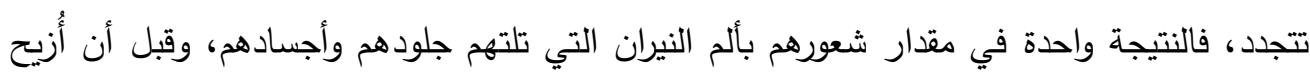

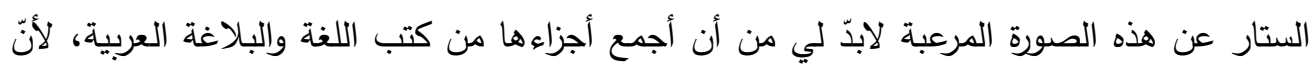

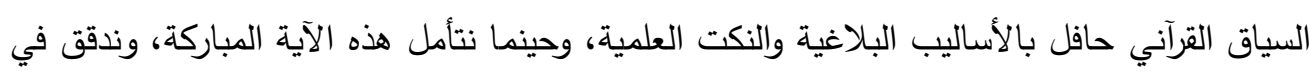
أصوات الحروف المكوّنة لها نشعر بوقع الألم، ونتلمّس شدّته، فقد بدأت هذه الآية بأداة توكيد (إنّ) ثم

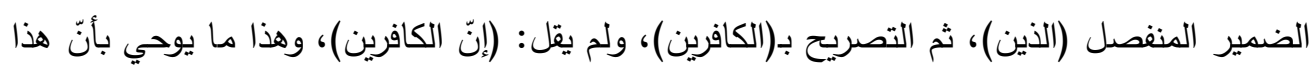

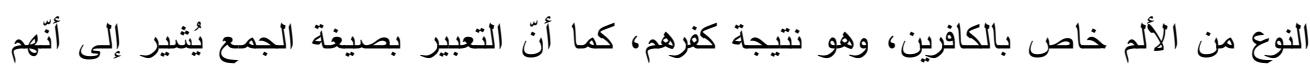

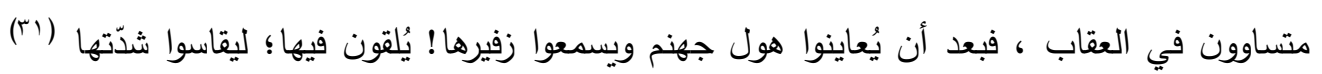

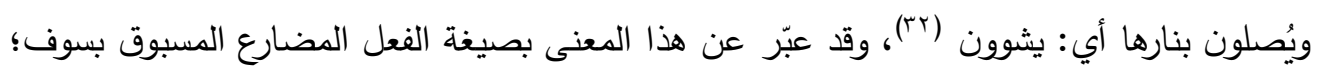

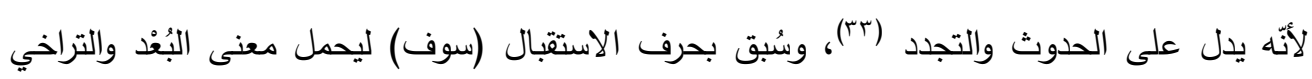
وجَعْل الفعل (نُصليهه) خالصاً للاستقبال فقط (๕َr)، وقد عبّر عن الجلود بصيغة التتكير؛ لأنّ النكرة تدل على العموم والثياع (־))، أي: كل قطعة جلد في جسدهم سوف تصلى وتبلى ثم تتجدد، مبالغة

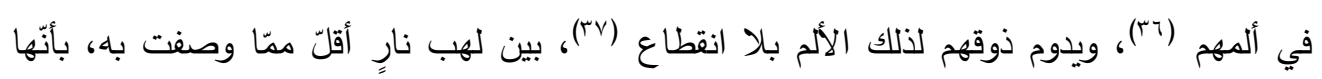

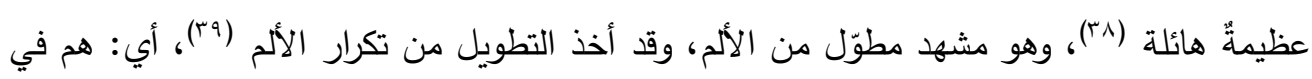

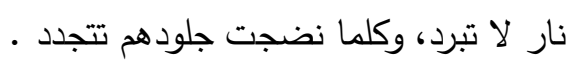

يتبيّن ممّا تقدم بأنّ الآية المباركة تصوّر رحلة الألم التي يقطعها الكافرون في ظلمة العقاب! وبين

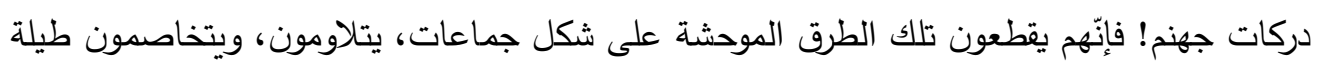

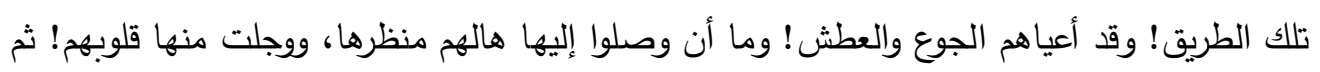

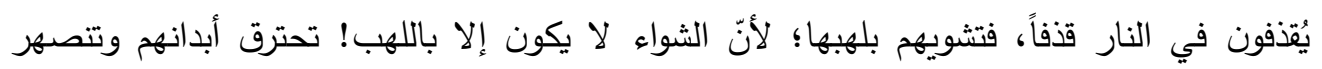


العـــــــد السابع وإلثلاثون

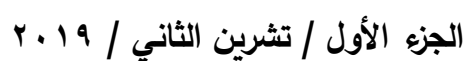

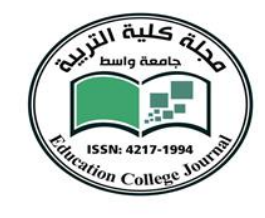

جامعة واسط مجلـــة كليـــــة التربيــــة

جلودهم فلم يبقَ جزءً من جسمهم لم تحرقه النار ، حتى جفون أعينهم! ذلك الجزء الرقيق من البدن!

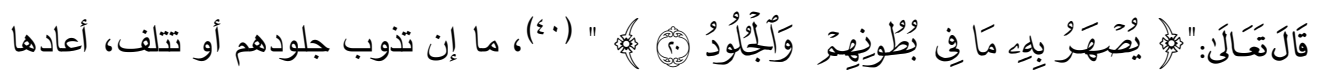

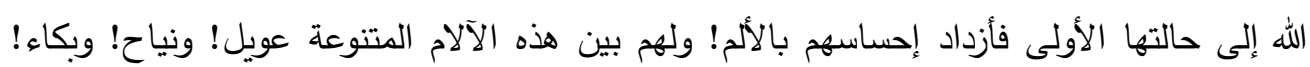

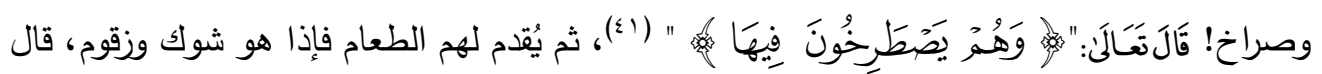
تعالى:

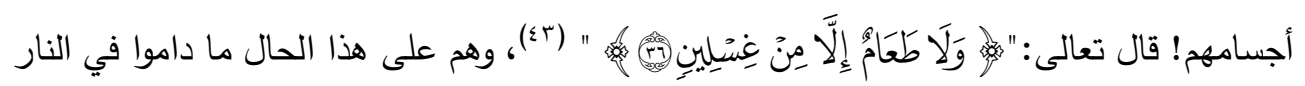

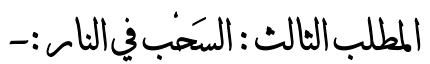

لقد خص الله الوجه بأنواع الألم، وفي إحدى آيات سورة القمر وصف سبحانه بعض العاصين بأنهّ

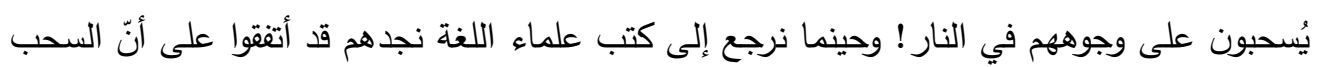

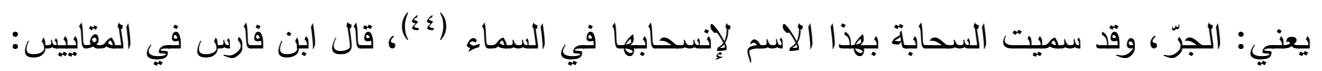

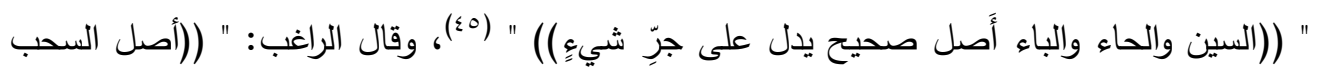

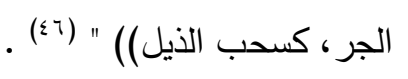

نستتتج مما سبق من كلام أهل اللغة أنّ السحب في النار : هو جرُ العاصين وكل من حقّ عليهر

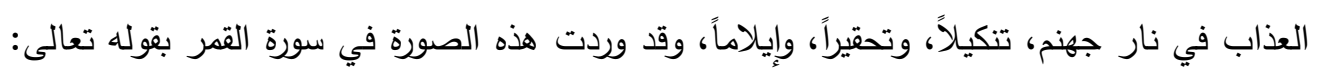

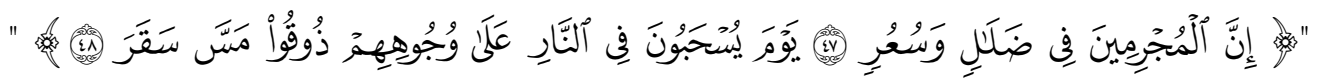

يبيّن الله سبحانه حال الكافرين والمشركين، وكل من أتخذ غير الإسلام ديناً، بأنّهم في الدنيا في شقاء

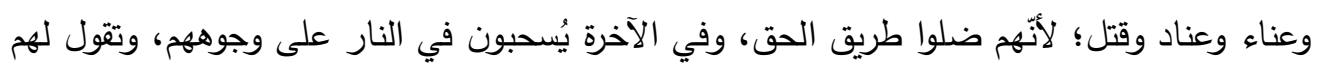

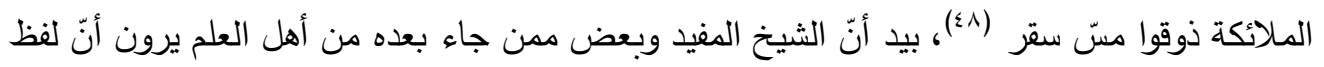

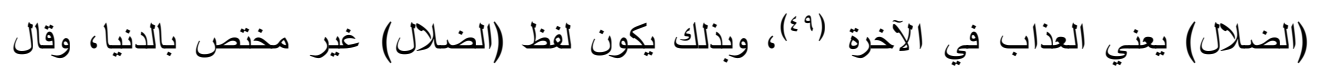

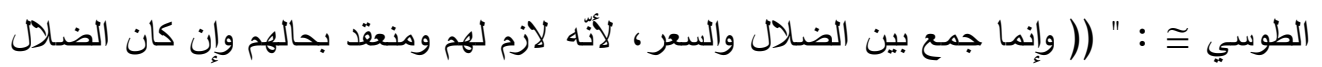

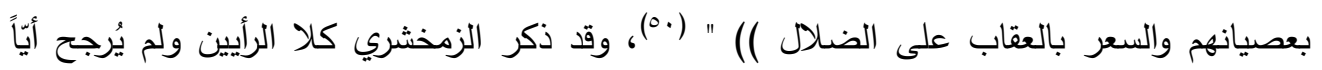

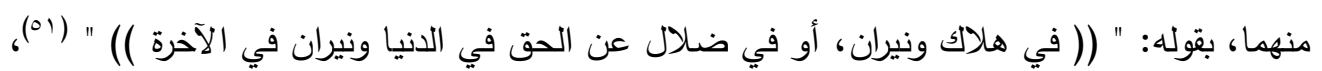
ووافقه على ذلك أبو السعود (مثان. 
العـــــــد السابع وإلثلاثون

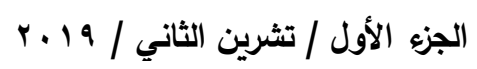

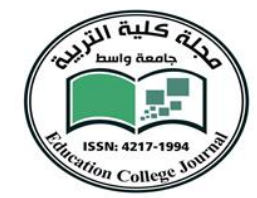

جامعة واسط مجلـــة كليـــة التربيــة

لقد وصف الله سبحانه أهل العذاب بأنّهم يُجرون في النار على وجوههم إهانة لهم ومبالغة في ألمهم،

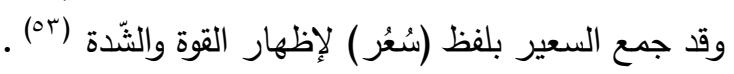

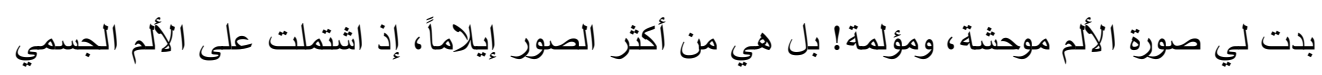

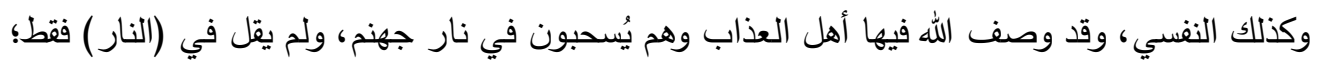

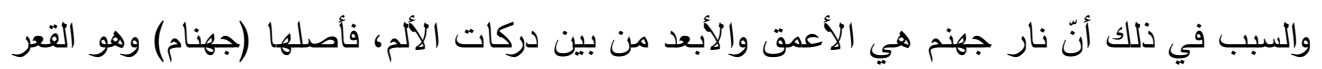

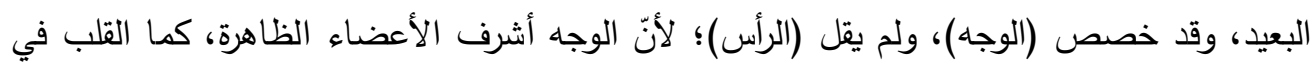

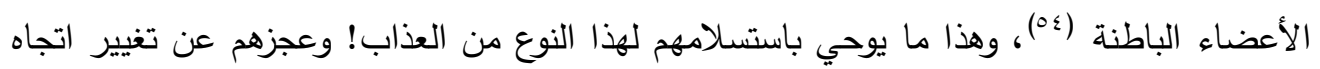

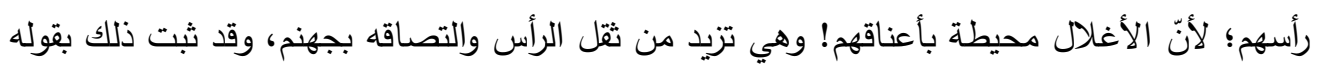

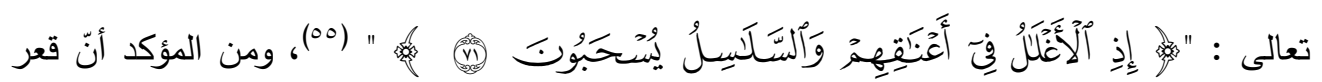

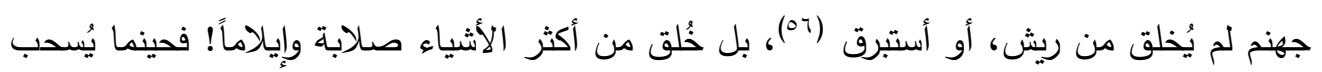

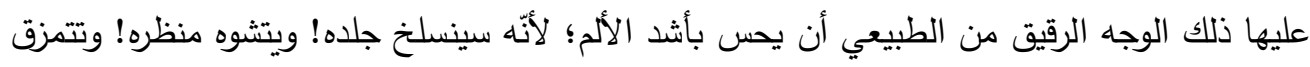

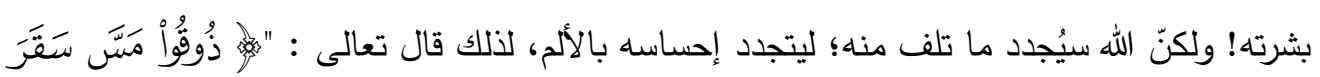

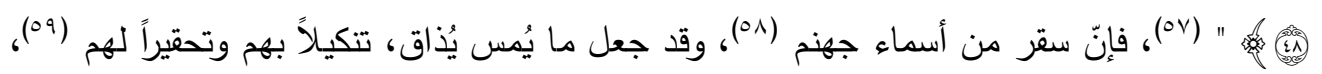

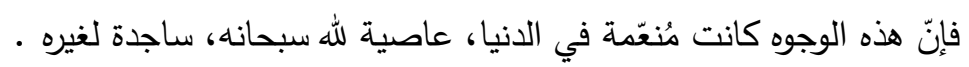

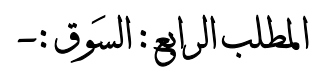

يأتي لفظ السوق بمعنى مجموعة من الناس، أو بمعنى الحث على السير (·־) لجهة معينة، وهو

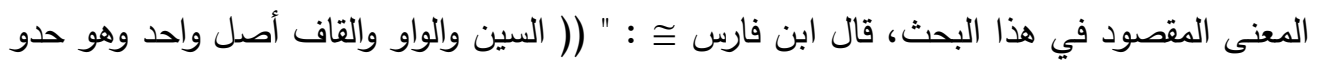

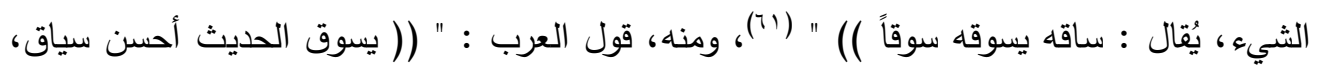

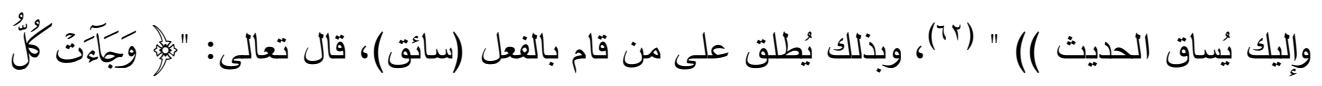

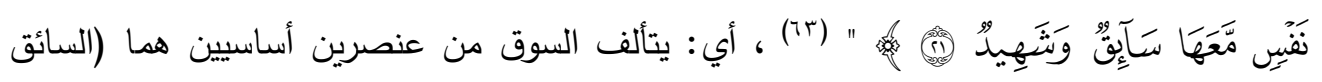
والمسوق) .

وقد ذكر الله سبحانه صورة سوق أهل النار إلى دركات الألم في سورة الزمر المباركة بقوله تعالى: "هورة

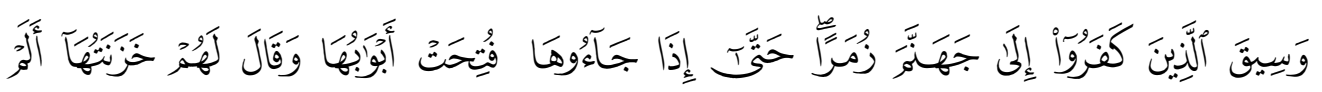

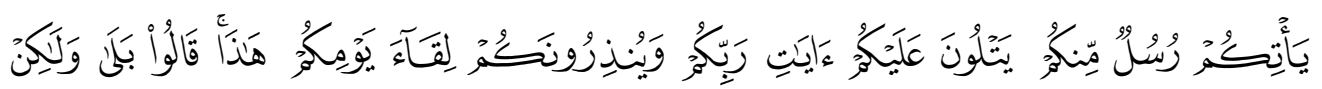


العـــــــد السابع والثلاثون

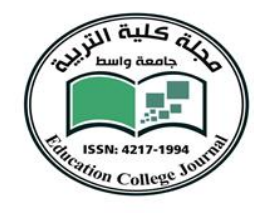

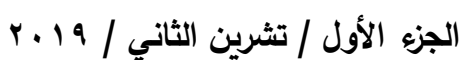

جامعة واسط

مجلــــة كليــــة التربيـــــة

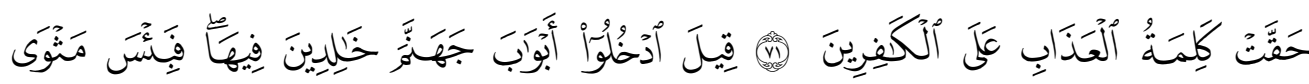

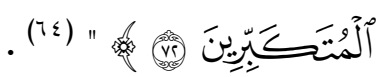

يُساق الكفار أفواجاً باتجاه جهنم، حتى إذا وصلوا جهنم فُتِحَتْ أَبوابها وكانت قبل ذلك مغلقة، ونُشرت الصحف بعد أن كانت مطوية، فقال لهم خزنة النار : ألم يأتكم رسل من أنفسكم يقرأون عليكم القرآن وينذرونكم البعث؟ هذا السؤال من باب الإنكار والتهجين والتقريع، وقد كان له دور في إثارة الألم • النفسي فيهم قالوا : بلى فعلوا ولكن وجبت كلمة العذاب، فقال لهم خزنة جهنم: أدخلوا جهنم خالدين (70)، أي:

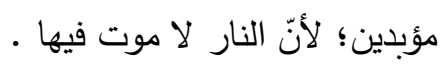
لم يكن سوق الكافرين إلى جهنم مجرد السير باتجاه النار، بل كانت الطريق إلى مثواهم الأخير

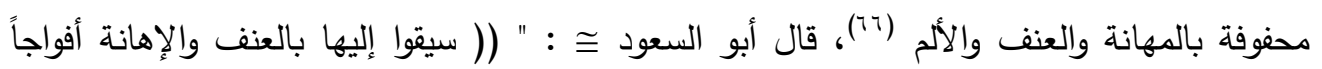
متفرقة بعضها في إثر بعض مترتبة حسب ترتب طبقاتهم في الضلالة )) " (TVآ) .

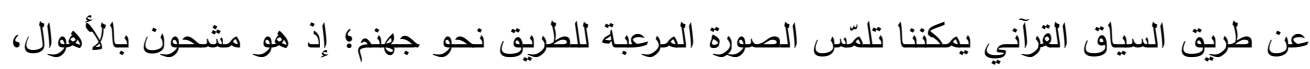

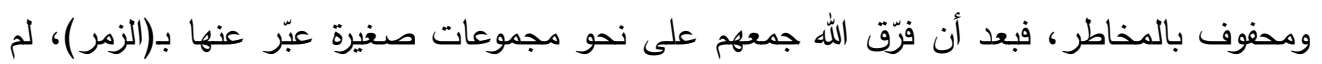

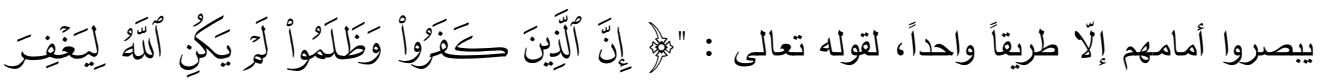

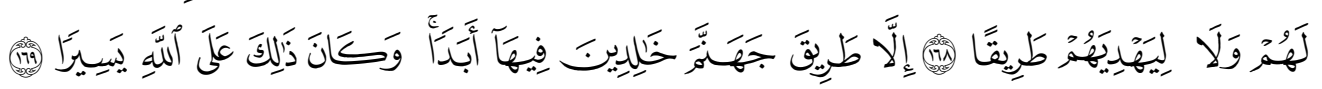

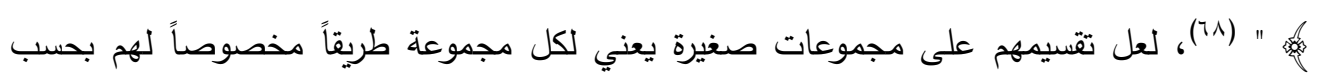
جرمهُ؛ لأنّ الطرق المؤدية إلى جهنم مختلفة من حيث ما تسببه من رعب وألم لمن يُساقون فيها، وكل طريق يؤدي إلى باب من أبواب جهنم . بعد أن قطعوا تلك الطريق التي لم يكثف الله - صراحة - عمّا فيها من أهوال، وآلام؛ تهويـلاً لها! حتى انتهت بهم عند أبواب جهنم، من المؤكد أنّ أبوابها بلغت من الحجم ما يملأ القلب رعباً! ويزيدهم

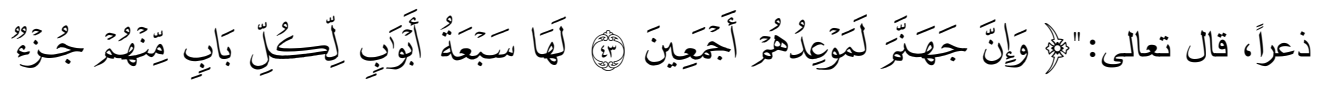

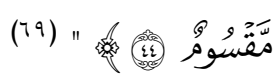

ما إن وصلوا إليها فُتحت تلك الأبواب إيذاناً باستعدادها التام لحرق وإيلام كل من دخلها، وقد أستعار صورة الكائن الحي للنار ؛ لأنها علمت ! ورأت! واستقبلت وتهيأت لساكنيها! وفتحت أبوابها دون تدخّل 
العـــــــد السابع وإلثلاثون

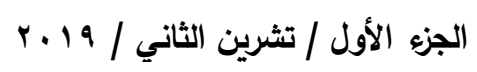

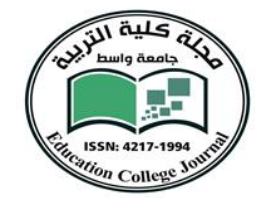

جامعة واسط

مجلـــة كليـــة التربيــة

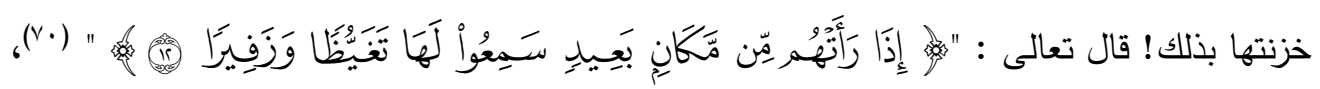

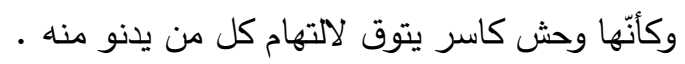

كما أنّ فتح أبواب جهنم يوحي باستعجالها لتلتقهم بدركاتها؛ لأنها لم تفتح باباً واحداً بل كل الأبواب؛ لأبها

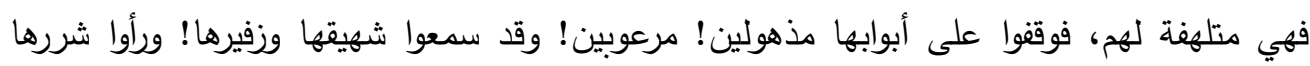
المتطاير ! وحميمها الذي سيكون شراباً لهم! في هذه اللحظة ندانئ ندموا على ما أسلفوا، وتمنوا لو أُعيدوا

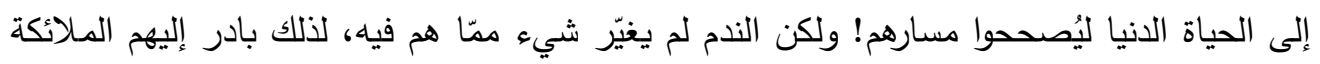
بسؤالهم ألم يأتكم نبي؟ وفي هذه اللحظة لا مجال للنكران والتهرب من الجواب! فأجابوهم بلى ولكئ فئنا

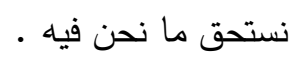

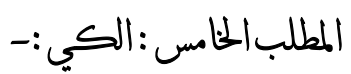

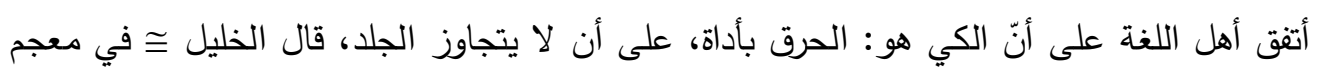

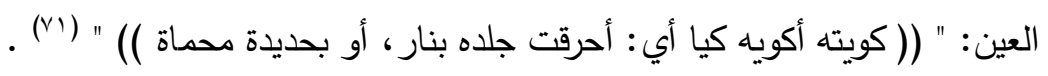

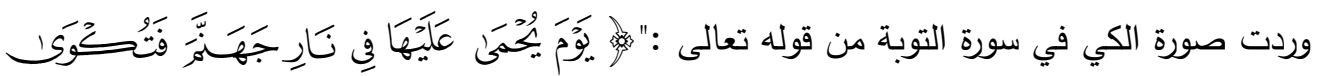

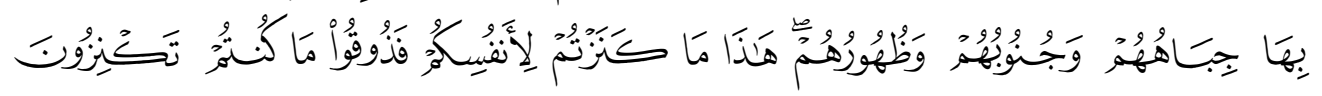

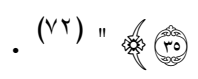
وقد فصّل الله سبحانه في هذه الآية الألم الذي يشعر به هؤلاء، تفصيلاً دقيقاً، وقد أستعمل صيغة

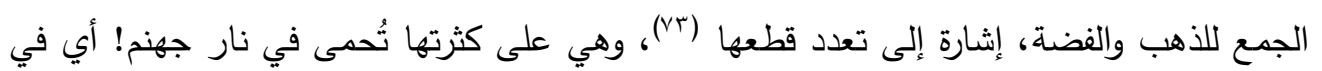

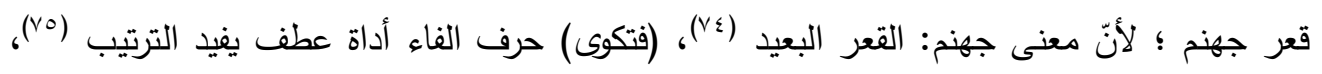

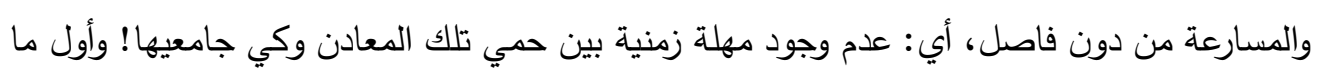

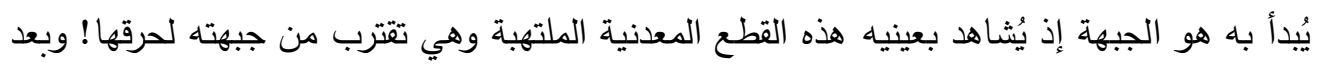

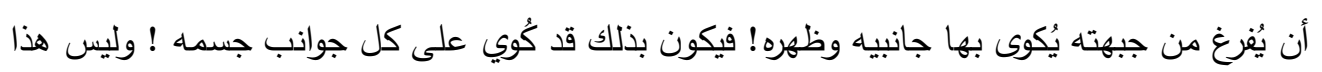

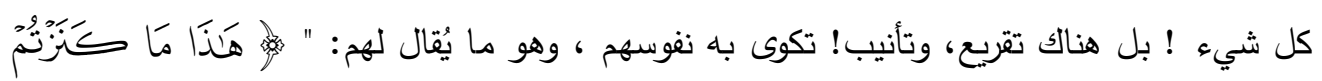

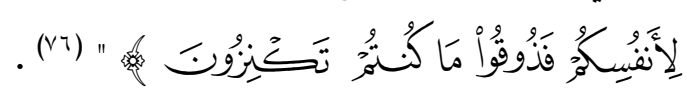

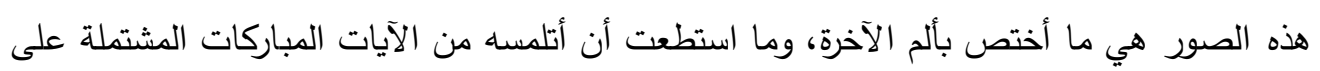

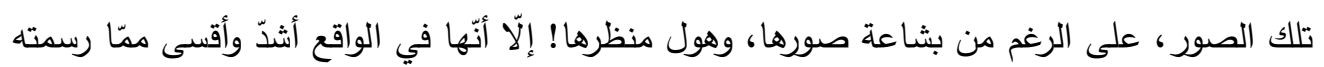

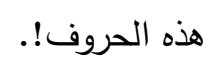


العـــــــدد السابع والثلاثون

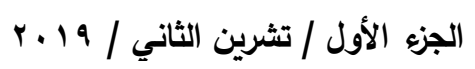

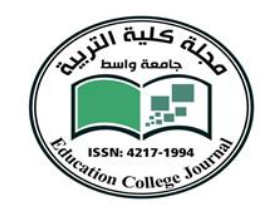

جامعة واسط

مجلـــة كليـــــة التربيــــة

الخاتمة

بعد كل ما تقدم من صورٍ للألم يمكن أن نستخلص منها عدة نتائج، أهمها: - - إنّ الله سبحانه عادل، حكيم، رؤوف بعباده، رحيم بهم، وإنّ الألم الذي توعّد به المنحرفين عن تعاليمه وأوامره، ما هو إلّا نتيجة أعمالهم، وسلوكهم في الحياة الدنيا .

- - ألم حياة الآخرة أشد وأقسى من كل آلام الحياة الدنيا، وإن كنا نشعر بأنّ بعضها قاسٍ، ومؤلم . - - ذكر الله سبحانه تلك المشاهد المروّعة في القرآن الكريم، وذكر ما يقابلها من مشاهد تبعث الطمأنينة، والراحة، والنعيم الذي لا يفنى، لبيان حال الخلق يوم القيامة، والكشف عن هذين

$$
\text { المسارين؛ لعدم وجود غيرهما يومئذٍ . }
$$

- - إن ذكر تلك الصور كان أسلوباً من أساليب تربية الخلق، وتهذيب سلوكهم، وصقل أرواحهم، للارتقاء بهم إلى درجة يستحقون بها دخول الجنة.

- لا يمكن للحروف أن تحل مدل المشاهدة الحقيقية لتلك الصور، على الرغم من بشاعة صور الألم في الآخرة، إلّا أنّها في الحقيقة أشد ألماً، وأكثر رعباً .

- كلّما زاد عدد الحواس المتحسسة للألم، زادت نسبة تألمهم وشعورهم بذلك الألم . - - إنّ الله رؤوف رحيم، وقد ذكر في أكثر من موضع من القرآن الكريم بأنّه سبحانه غفّار للذنوب، فإنّ العبد إذا أسرع إلى التوبة قبل انتقاله إلى تلك الحياة (حياة الآخرة)، كانت تلك التوبة درعاً له من ذلك الألم ودركاته، وسبباً للفوز بالجنة . 
العـــــــد السابع وإلثلاثون

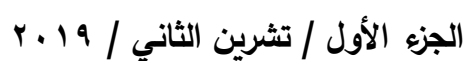

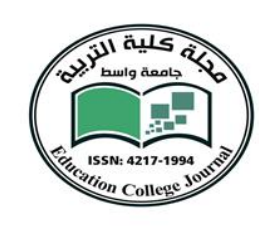

جامعة واسط

مجلـــة كليــــة التربيــــة

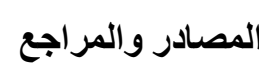

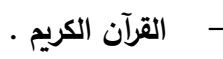

الإتقان في علوم القرآن، عبد الرحمن بن أبي بكر، جلال الدين السيوطي، (ت:111)،هـ)، تحقيق: محمد أبو الفضل

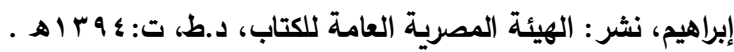

إرشاد العقل السليم إلى مزايا القرآن الكريم، أبي السعود محمد بن محمد العمادي، (ت:ب^هـه)، نشر: دار إحياء التراث

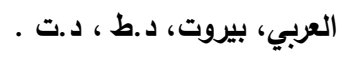

أساس البلاغة، أبو القاسم محمود بن عمرو بن أحمد، الزمخشري جار الله، (ت:^ץهـه)، تحقيق: محمد باسل عيون

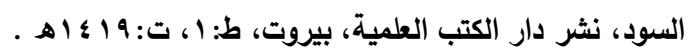

- الأطلس العلمي فيزيولوجيا الإنسان، زهير الكرمي، وسهام العقاد، ومحمد سعيد، تحقيق: عصام المياس وحافظ قبيسي،

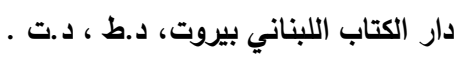

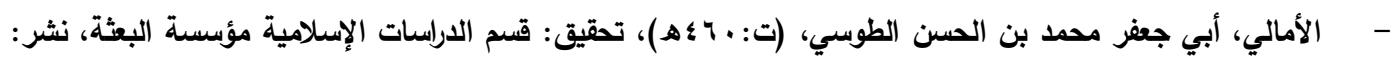

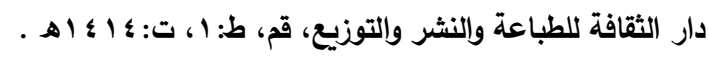

الأمثل في تفسير كتاب الله المنزل، ناصر مكارم الثيرازي، طبع ونشر دار أحياء التراث العبب، لبنان، ط:؟،

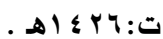

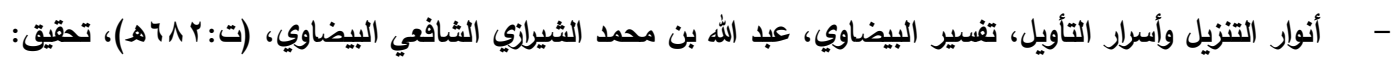

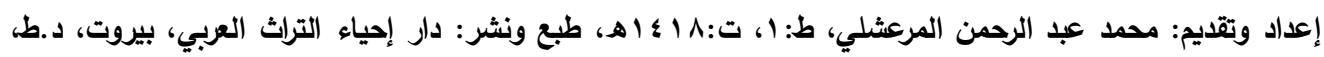
د.ت .

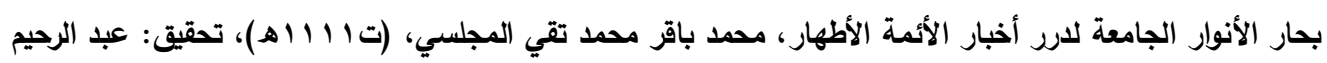

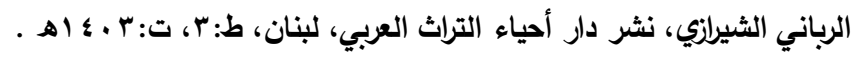

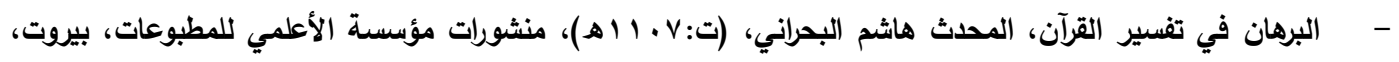
ط:Y

تاج العروس من جواهر القاموس، محب الدين أبي فيض السيد محمد مرتضى الحسيني الواسطي الزبيدي الحنفي،

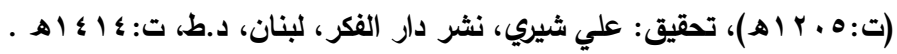

- - التبيان في تفسير القرآن، أبو جعفر محمد بن الحسن بن علي بن الحسن الطوسي، (ت: . 7 ؛هـ)، تحقيق: أحمد حبيب

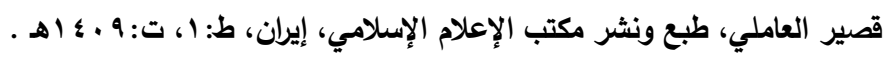


العـــــــد السابع والثلاثون

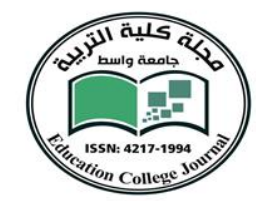

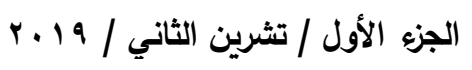

جامعة واسط

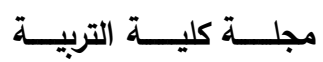

التحرير والتنوير، تحرير المعنى السديد وتنوير العقل الجديد من تفسير الكتاب المجيد، محمد الطاهر بن محمد بن

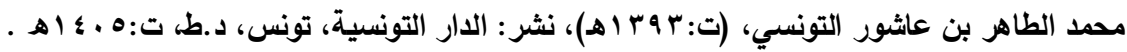

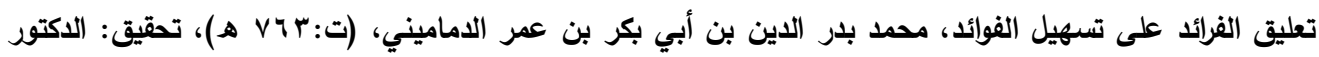

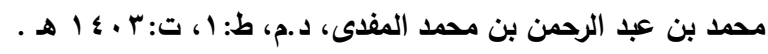

تفسير البحر المحيط، أثير الدين محمد بن يوسف بن حيان الغرناطي الأندلسي، (ت:0 ؛ Vه)، تحقيق: عادل أحمد عبد

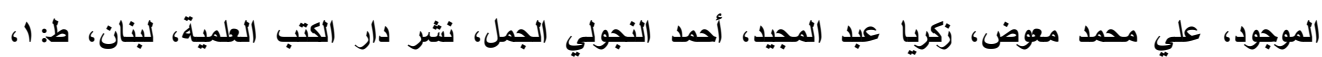

تفسير الراغب الأصفهاني، أبو القاسم الحسين بن محمد المعروف بالراغب الأصفهانى، (ت:؟ .0هـ)، تحقيق: د. محمد

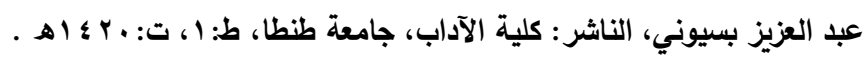

التفسير الصافي، المولى محسن الفيض الكاثاني، (ت: 19 ـ 1هـ)، تحقيق: حسين الأعلمي، طبعة: مؤسسة الهادي،

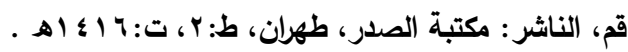

تفسير القرآن العظيم الجلالين، جلال الدين محمد بن أحمد المحلي، وجلال الدين عبد الرحمن بن كمال الدين السيوطي،

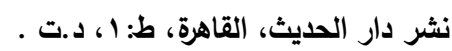

تفسير القرآن المجيد، الثيخ المفيد، (ت:ب إ؛ه)، تحقيق: السيد محمد علي أيازي، مطبعة مكتب الإعلام الإسلاهي،

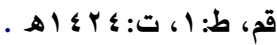

تفسير القرآن للقرآن، عبد الكريم يونس الخطيب، (ت: . 9 1 اهـ)، نشر : دار الفكر العربي، القاهرة، د.ط، د.ت.

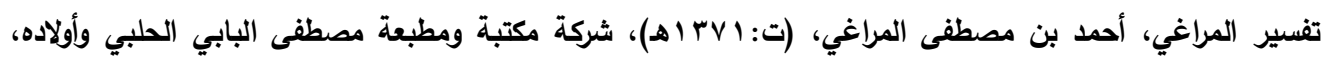

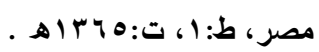

تفسير مجاهد، مجاهد بن جبر المخزومي التابعي أبو الحجاج، (؛ ـ الهـ)، تحقيق: عبد الرحمن الطاهر محمد السورتي،

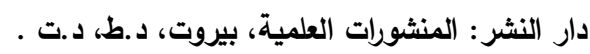

تفسير مقاتل بن سليمان، أبو الحسن مقاتل بن سليمان بن بثير الأزبي البلخى (ت: . 0 اهـ)، تحقيق: عبد الله محمود

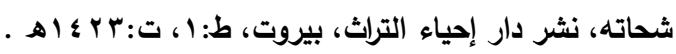

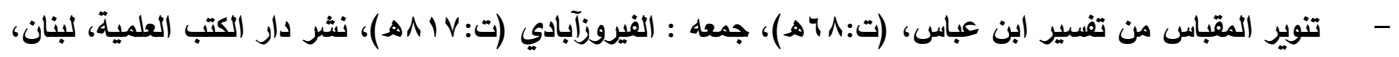
د.ط، د.ت . توير المقباس 
العـــــــد السابع والثلاثون

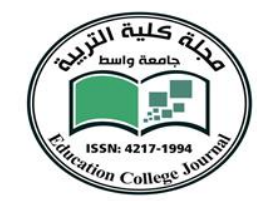

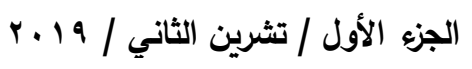

جامعة واسط

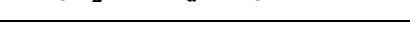

جامع البيان عن تأويل آي القرآن، محمد بن جرير بن يزيد بن خالد الطبري أبو جعفر، (ت: . اسبه)، نشر دار الفكر،

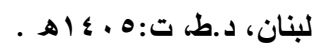

الخصائص، أبو الفتح عثمان بن جني الموصلي، (ت: ج 9 بهـ)، الناشر: الهيئة المصرية العامة للكتاب، ط: ؛، د.ت . زهرة التفاسير، محمد بن أحمد بن مصطفى بن أحمد المعروف بأبي زهرة، (ت: ؛ 9 ب اهـ)، دار النشر : دار الفكر العربي،

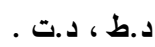

شرح المقدمة المحببة، طاهر بن أحمد بن بابشاذ، (ت:9 \ \هـ)، تحقيق: خالا عبد الكريم، نشر : المطبعة العصرية،

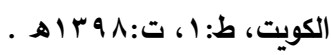

الصحاح تاج اللفة وصحاح العربية، أبو نصر إسماعيل بن حماد الجوهري، (ت:r arهـ)، تحقيق: أحمد عبد الغفور

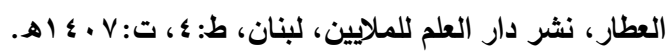

صفوة التفاسير، محمد علي الصابوني، الناشر : دار الصابوني للطباعة والنشر والتوزيع، القاهرة، ط: ا، ت: V إ اهـ ـ علل النحو، محمد بن عبد الله بن العباس أبو الحسن ابن الوراق، (ت: I I IهA)، تحقيق: محمود جاسم محمد الارويش،

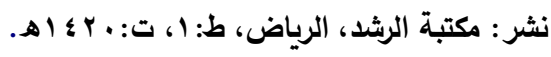

العين، الخليل بن أحمد الفراهيدي، (ت: • اهـ)، تحقيق: د. مهاي المخزومي، د. إبراهيم السامرائي، طبعة مؤسسة

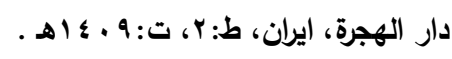

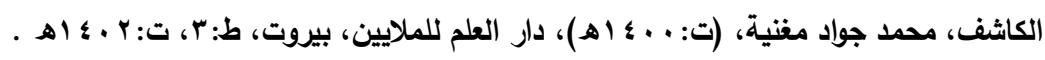

الكثاف عن حقائق التنزيل وعيون الأقاويل في وجوه التأويل، أبو القاسم محمود بن عمر الزمخشري الخوارزمي،

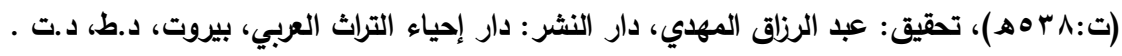

اللباب في علوم الكتاب، أبو حفص سراج الدين عمر بن علي بن عادل الحنبلي الامشقي النعماني، (ت:هوهـه)،

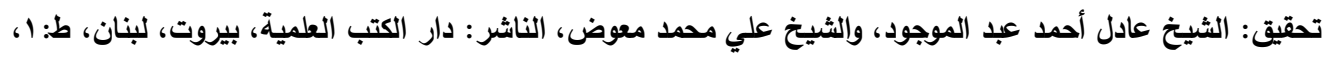

لسان العرب، ابن منظور محمد بن مكرم بن علي الخزرجي الأفريقي ( ت: 11 الهـ )، نثر دار صادر، لبنان، ط: 1، د.ت .

- - مجاز القرآن، أبو عييدة معمر بن المثنى التيمى البصري، (ت:9 . rهـ)، تحقيق: محمد فواد سزگين، نشر: مكتبة

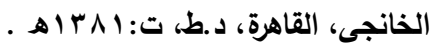


العـــــــد السابع والثلاثون

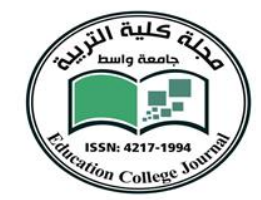

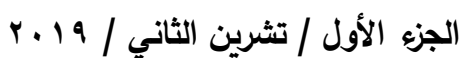

جامعة واسط

مجمع البيان في تفسير القرآن أبي علي الفضل بن الحسن الطبرسي، (ت:^؛ـهـ)، تحقيق: لجنة من العماء

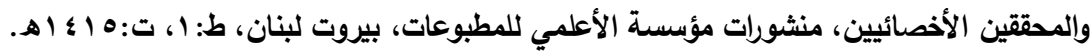

- مشاهد القيامة في القرآن، سيد قطب، مطبعة أنوار دجلة، بغداد البتاوين، د.ط، د.ت.

معاني القرآن وإعرابه، إبراهيم بن السري بن سهل، أبو إسحاق الزجاج، (ت: إسهـ)، تحقيق: عبد الجليل عبده شلبي،

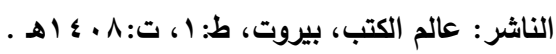

معاني القرآن، أبو الحسن المجاشعي بالولاء، البلخي ثم البصري، المعروف بالأخفش الأوسط (ت:ه ابهـ)، تحقيق:

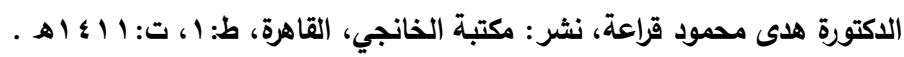

معاني القرآن، أبو جعفر النحاس أحمد بن محمد، (ت:^rشهـ)، تحقيق: محمد علي الصابوني، الناشر: جامعة أم

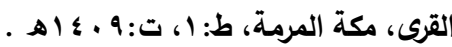

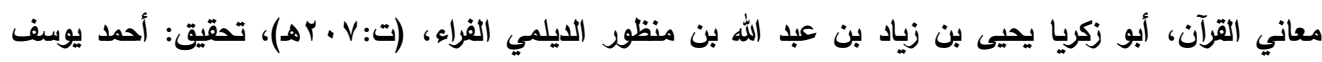

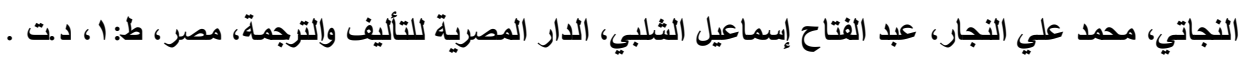

معاني النحو، د. فاضل صالح السامرائي، نشر : دار الفكر للطباعة والنشر والتوزيع، الأردن، ط: ا، ت: . ب ؛ اهـ . معجم مقاييس اللفة، أبي الحسين أحمد بن فارس بن زكريا، (ت ه و بهـ)، تحقيق: عبد السلام محمد هارون، نشر دار

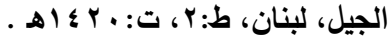

مفردات ألفاظ القرآن، أبو القاسم الحسين بن محمد الراغب الاصفهاني، (ت:r • هـ)، تحقيق وتعليق: أبو عبد الله

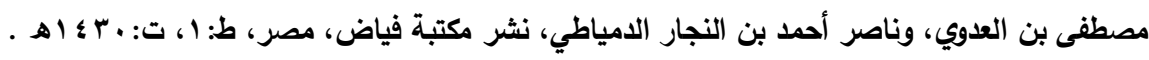

المقتضب، محمد بن يزيد بن عبد الأكبر الثمالي الأزدي أبو العباس، المعروف بـ(المبرد)، (ت: ع بهـ)، تحقيق: محمد

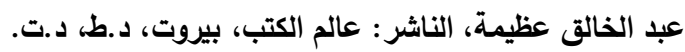

الميزان في تفسير القرآن، محمد حسين الطباطبائي، (ت:؟ • أهـ)، تصحيح وإثراف الثيخ حسين الأعلمي، نشر

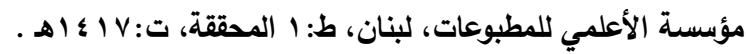

- - الهاية إلى بلوغ النهاية في علم معاني القرآن وتفسيره، وأحكامه، وجمل من فنون علومه، أبو محمد مكي بن أبي

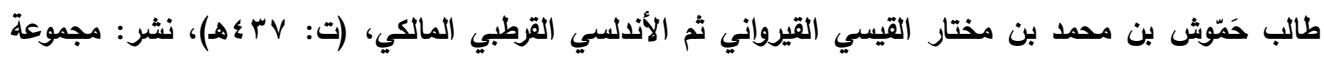

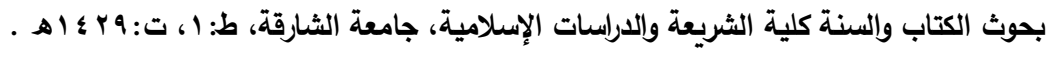


العـــــــد السابع والثلاثون

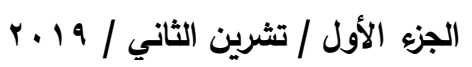

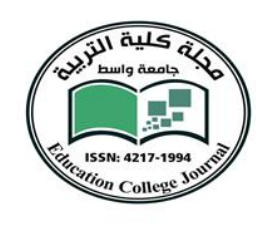

جامعة واسط مجلـــة كليــــة التربيـــة

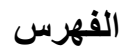

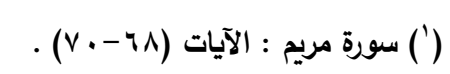

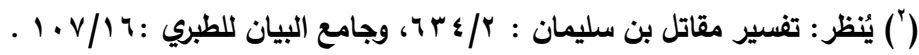

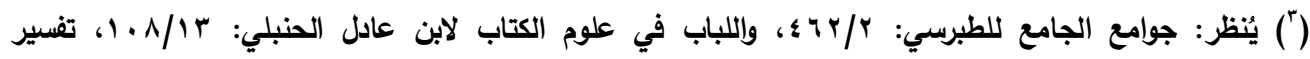

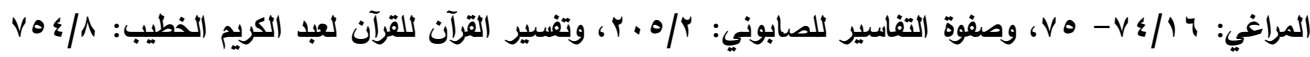

.v०0-

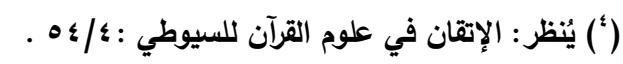

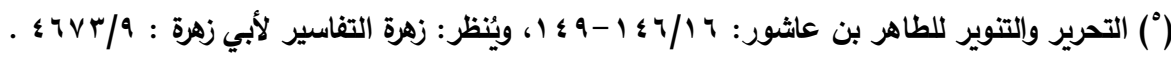

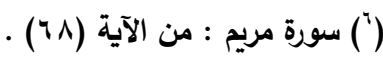

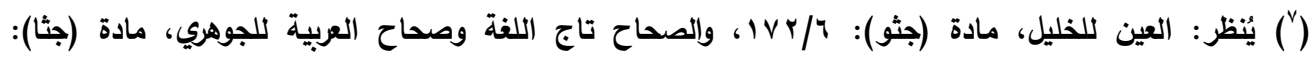

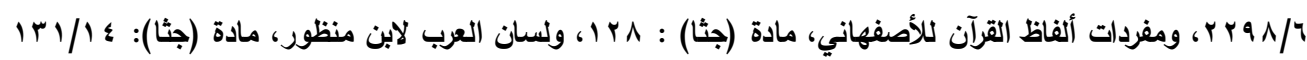

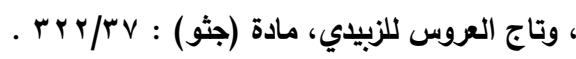

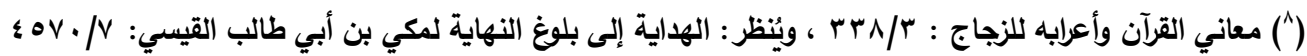

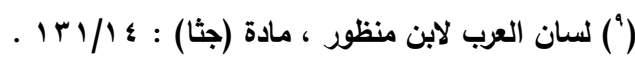

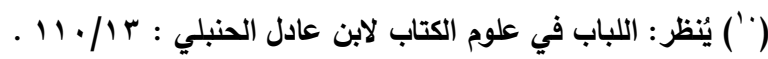

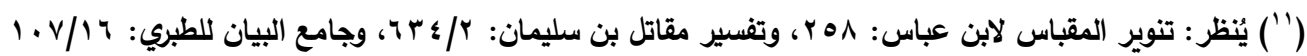

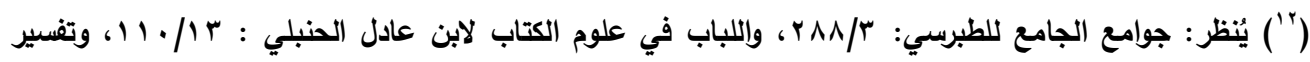

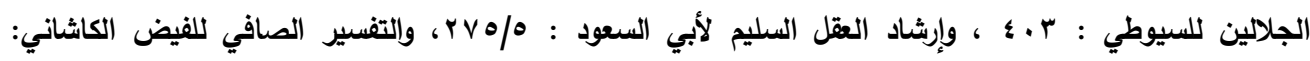

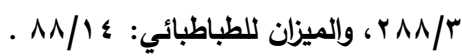

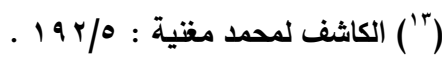

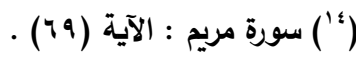

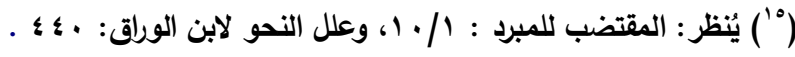

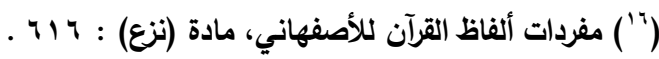

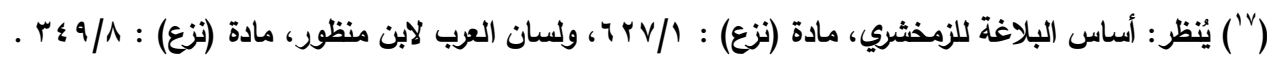

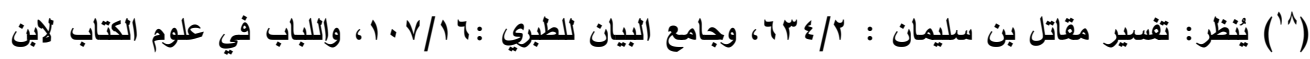

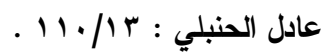

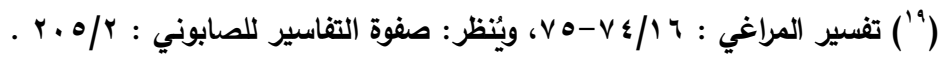

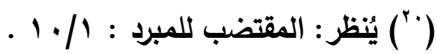

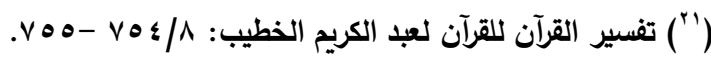

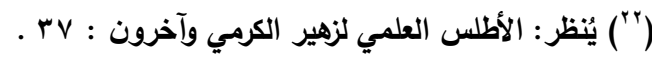

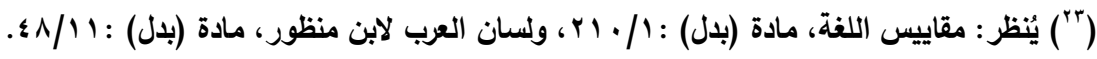


العـــــــد السابع والثلاثون

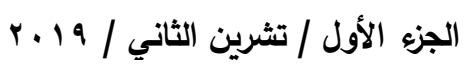

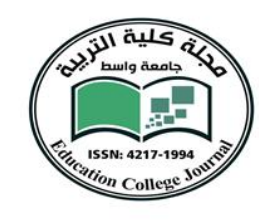

جامعة واسط مجلـــة كليــــة التربيــــة

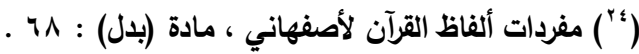

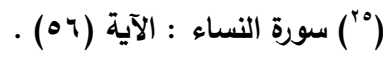

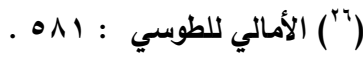

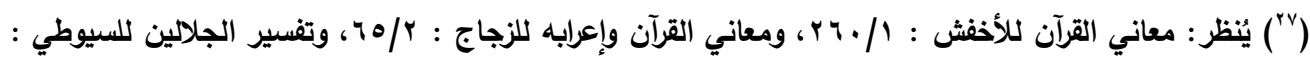

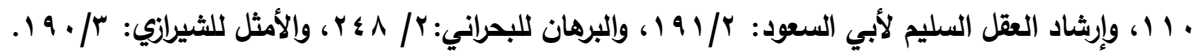

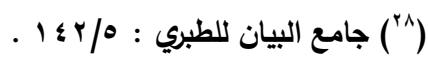

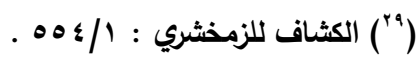

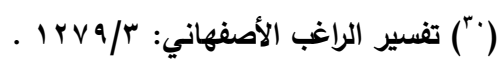

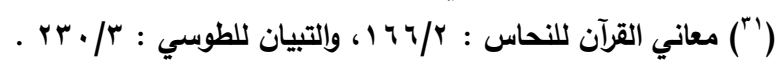

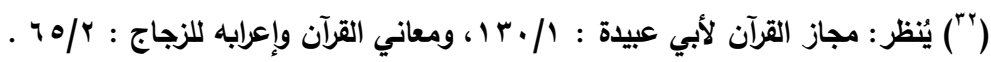

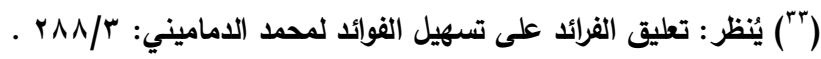

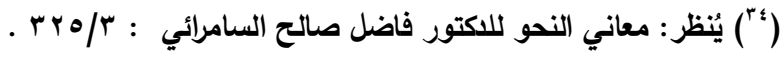

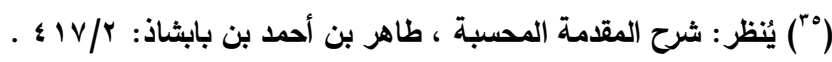

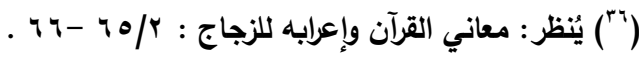
(")

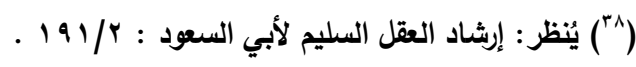

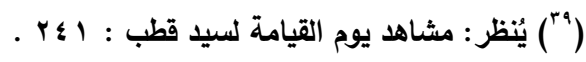

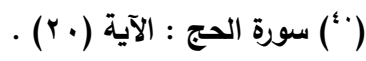

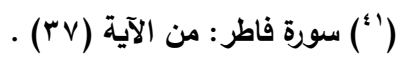

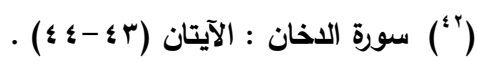

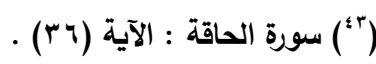

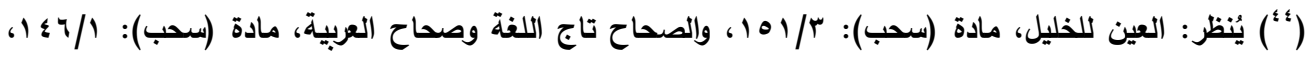

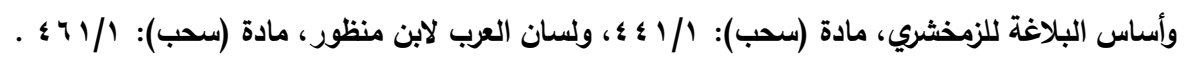

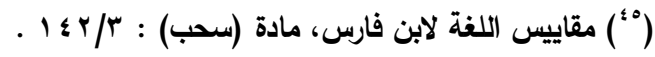

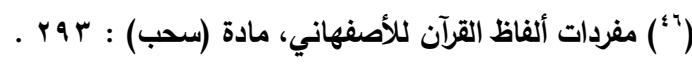

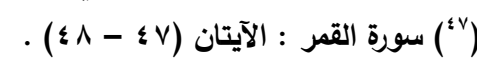

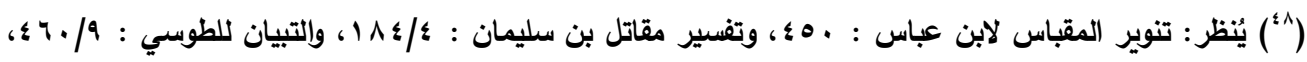

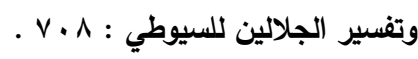

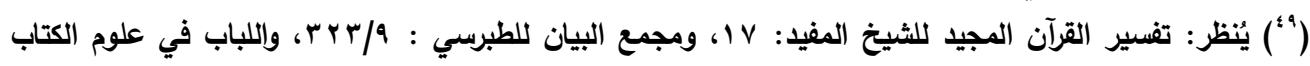

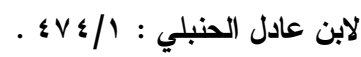

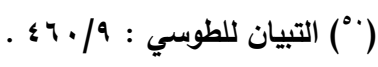


العـــــــد السابع والثلاثون

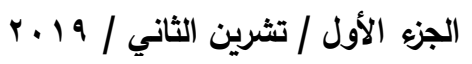

جامعة واسط

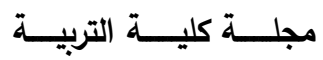

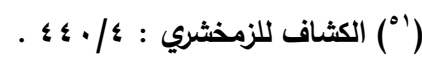

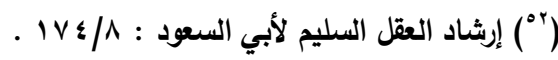

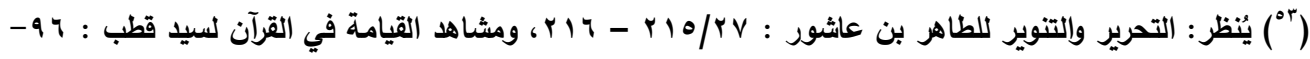

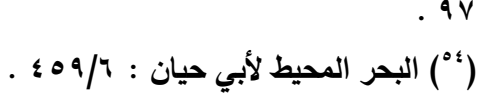

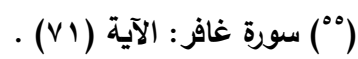

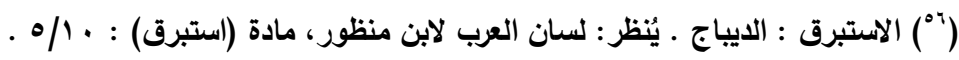

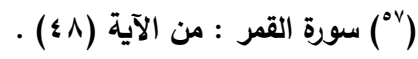

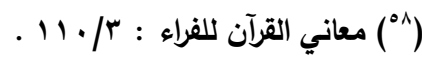

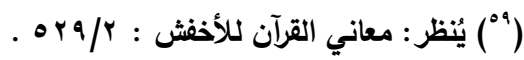

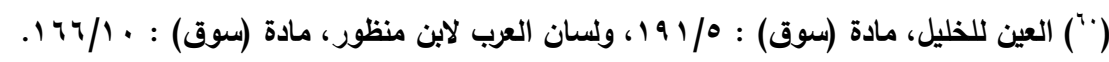

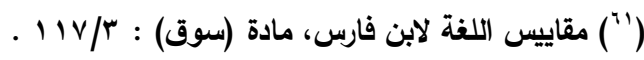

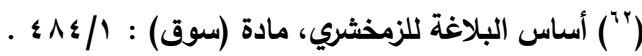

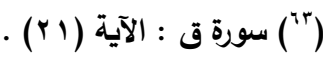

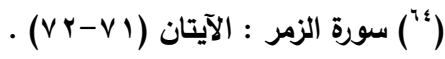

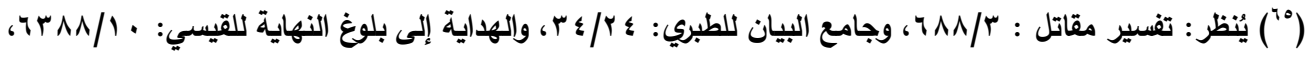

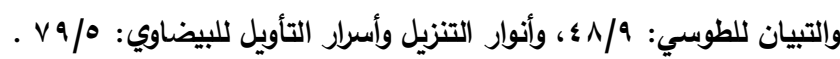

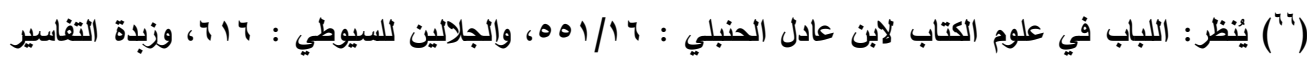

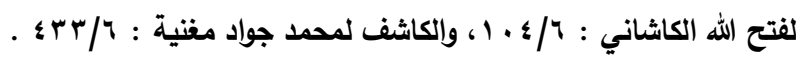

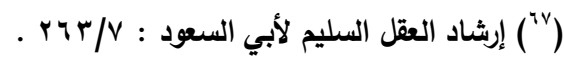

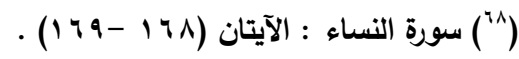

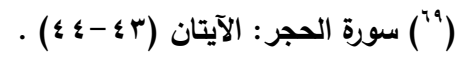

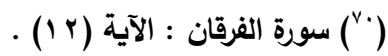

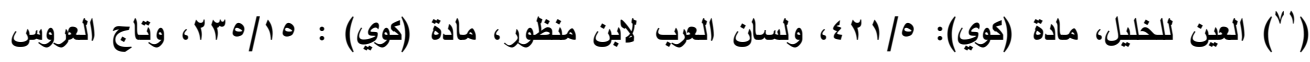

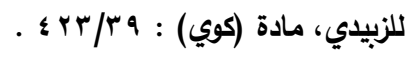

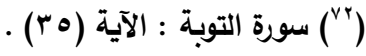

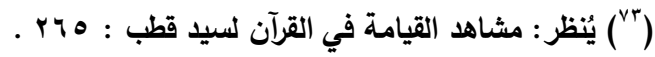

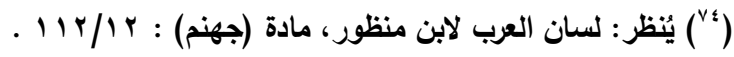

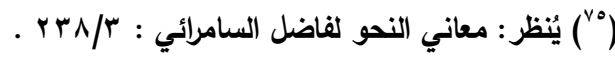

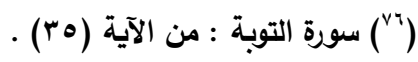

